\title{
Designing a Network and Systems Computing Curriculum: The Stakeholders and the Issues
}

\author{
Grace Tan \& Anne Venables \\ Victoria University, Melbourne, Victoria, Australia
}

Grace.Tan@vu.edu.au; Anne.Venables@vu.edu.au

Executive Summary

Since 2001, there has been a dramatic decline in Information Technology and Computer Science student enrolments worldwide. As a consequence, many institutions have evaluated their offerings and revamped their programs to include units designed to capture students' interests and increase subsequent enrolment. Likewise, at Victoria University the trend of declining student numbers warranted examination of the existing computing programs and their viability; extensive reviews recommended that all existing undergraduate computing programs should be replaced by a single, new, three-year offering in network and systems computing. The decision was supported by extensive market research and evidence of a strong market demand and future needs for networking and systems specialists in Australia.

In designing this new degree program, it was necessary to identify the needs of various stakeholders, such as students, academics, the university, industry, and the professional body. Surveys of recent graduates and industry partners, reinforced by professional accreditation demands, indicated the need for a program to include up-to-date technical competencies and the development of work-readiness skills in students. Aware of University requirements, academics undertook considerable discussion with their peers and thorough research of similar programs elsewhere in preparation for the development of the curriculum in network and systems computing.

The resultant program structure is a divergence from the traditional computer science offering of our Faculty. It is innovative in its incorporation of industry-based certifications to allow students to gain relevant practical, hands-on work-related experience. The program consists of instruction in core competencies in networks and communications, supported by the teaching of skills in computer systems, programming, and database systems. Each of these proficiencies is further consolidated by professional development studies. The new program aligns with the University's strategic directions and satisfies professional body accreditation and it is expected to meet student expectations and fulfil a market need for graduates skilled in systems administration with networking expertise.

Keywords: network computing education, systems computing education, academic review, cur-

Material published as part of this publication, either on-line or in print, is copyrighted by the Informing Science Institute. Permission to make digital or paper copy of part or all of these works for personal or classroom use is granted without fee provided that the copies are not made or distributed for profit or commercial advantage AND that copies 1) bear this notice in full and 2) give the full citation on the first page. It is permissible to abstract these works so long as credit is given. To copy in all other cases or to republish or to post on a server or to redistribute to lists requires specific permission and payment of a fee. Contact Publisher@InformingScience.org to request redistribution permission. riculum development.

\section{Introduction}

Despite there being a strong job market for computing professionals worldwide, computer science student enrolments have been undergoing a dramatic decline since 2001 (Liu, 2007; Melymuka, 2006). The declining enrolments in both undergraduate and graduate computing 
programs will precipitate an information and communication technology (ICT) workforce crisis for the coming decade (Dychtwald, Erickson, \& Morison, 2006). In Australia, where the IT industry generates revenues of \$A65.7 billion or $8.7 \%$ of GDP, the numbers of ICT students has dropped 19\% nationally since 2002 and the federal government has identified the shortage of IT students as an issue requiring remedial action in the near future (Multimedia Victoria [MMV], 2007).

Against this backdrop, many institutions have evaluated their ICT offerings with a view to making them more attractive to students. The different strategies employed range from cosmetic changes with minor alterations in content and program titles, through to major shifts in programs' foci. These foci include interactive digital media, cross-disciplinary applications (like health informatics and embedded systems informatics), entertainment technologies, and game development (Clemson University, 2007; Monash University, 2007). Such revamped programs, through differentiation between themselves from their competitors, have been successful in attracting new enrolments by fulfilling the needs of the students and by meeting their expectations (Novotny \& Doucek, 2007; Sharda, 2007).

Since the early 1990s, Australian governmental changes to higher education funding models have impacted greatly on all curricula design and on how courses can be conducted (Skilbeck \& Connell, 1999). Today, the bottom line is that education institutes are expected to be financially independent and, within each institute, individual operating units need to attract sufficient students. Prior to 2004, Victoria University enjoyed strong student demand for each of its undergraduate ICT programs attracting students both onshore and offshore (in Hong Kong, China, and Malaysia). Since then, there has been a steady decline in students enrolling in computer science courses, which has posed a significant challenge for the ICT programs to remain financially viable. Accordingly, a number of University and external consultant reviews of the traditional computing program offerings were made in 2009 (Booth, 2009; Garnett, 2009). A critical reappraisal of the ICT programs was undertaken, and, overwhelmingly, the assessments recommended that the existing programs be discontinued; in their place, a new three-year degree in the area of Network and Systems Computing is to be introduced.

This paper outlines the rationale and method for designing the new Network and Systems Computing program together with the challenges in meeting the needs of various stakeholders through the alignment of the new curriculum. An examination of the proposed program structure will be detailed and the expected advantages of adopting the program will be discussed.

\section{Method for Designing a New Network \& Systems Computing Program}

In the search for a suitable program to replace the existing traditional computing offerings, analyses of online ICT employment opportunities was conducted in 2008 and early 2009. These analyses revealed an increasing trend in vacancies related to networks and systems management. More recently on 22 July 2009, Dang (2009) reported an increase of 5\% in contractor employment opportunities in the ICT sector. These trends coupled with investments in new broadband technologies by the Australian federal government predicates future growth in the network and systems areas of the ICT industry and, likely, a strong student demand.

Next, extensive market research was commissioned to assess interest in different undergraduate ICT programs; an independent online quantitative survey of 245 screened, intending respondents from within the region was undertaken. The response rate for females was $37 \%$ and $63 \%$ for males, with both secondary school leavers and mature age intenders being surveyed (Victoria University, 2009). The results indicated a strong awareness and preference for courses whose main strengths were in Information Technology fields, rather than the more traditional areas of 
Computing or Computer Science, with respondents exhibiting an awareness of the remunerative rewards within the ICT profession. This finding is further supported by the study conducted by the Australian Computer Society (ACS) in July 2009, which identified IT or Technology Professional as currently the most desirable career option for teenagers, even more appealing than the traditional careers of doctor, teacher, or lawyer (ACS, 2009). The ACS is the professional body responsible for all higher education ICT programs accreditation.

Given the evidence of a strong market demand and the future needs for networking and systems specialists, a suitable degree program intended to equip graduates with the skills required to gain an entry level position was proposed. Subsequently, industry experts were approached for comment on the draft proposal which included a degree outline, along with individual unit descriptions and a feedback form. Comments were solicited on the strengths and weakness of the draft, and overall the feedback was extremely positive concerning the relevance and focus of the proposal. Respondents were particularly enthusiastic about the potential of the new proposal to meet the growing market need for skilled graduates in systems administration with networking expertise. Specifically, they praised the inclusion of a significant learning in the workplace components through the facilitation of industry certifications within the program.

The mission for the program development team was to flesh the draft proposal into a program structure emphasizing a hands-on approach to learning with a strong industry focus. As pointed out by others (Finkelstein \& Hafner, 2002; Lui, 2007), IT programs need to have specialized studies that are of industrial strength and that are updated regularly to reflect the progress in the discipline. As well, any IT program should focus on the balance between vocational and intellectual demands in order to enhance graduate employment prospects. So by incorporating opportunities for industry certifications within the program, graduates would have the competitive edge for the different careers in the field of network and systems computing in sectors including government, banking and finance, retail, and manufacturing.

\section{Meeting the Requirements of Stakeholders}

Without question the most significant challenge for any IT program development is meeting the expectations and requirements of the stakeholders (Gruba, Moffat, Sondergaard, \& Zobel, 2004; Henkel \& Kogan, 1999). The stakeholders for this program development are students, academics, the University, industry, and the professional body. In conducting an analysis of each group's major interests, surveys conducted of our recent graduates working within ICT industry revealed that the prime issue of importance when designing a suitable IT curriculum was relevancy. From their perspective, any program must develop up-to-date technical competencies, as well as workreadiness skills in students, as preparation for their early careers. Not surprisingly, surveys querying other industry consultants reiterated that the same qualities were necessary skills for their incoming graduates. Examination of the accreditation requirements of the professional body reiterates the same message (ACS, 2003). To achieve suitable vocational outcomes, academics are guided by professional bodies' recommendations for appropriate discipline content whilst being mindful that program content needs to comply with internal university policies, as noted by Gruba et al. (2004).

\section{Academics}

The primary focus for academics when designing a new IT program relates to the objectives of excellence, currency, and relevance of content. The challenge is in preparing a well-rounded curriculum that develops a broad set of technical and soft skills while meeting students' vocational expectations. Both Gruba et al. (2004) and Hurst et al. (2001) concur with us that the primary driving force for academics involved in the teaching of the IT degree program is the validity and value of curriculum for students, both current and prospective. 
In determining possible themes and relevant content for the proposed program in networks and systems computing, much research of other suitable programs was undertaken. Additionally, many in-house discussions were conducted, particularly examination of likely competitors' offerings were made. External consultations with our ICT graduates and industry partners were sought to help distil the most appropriate program structure.

\section{Students}

Earlier research undertaken at Victoria University by Venables, Tan, Devi Nagappan, \& Ghous (2006), found that current ICT students were very pragmatic in their approach to studies. Their expectations were that a degree program be professionally accredited, incorporate cutting edge technologies, and be well considered by employers. Intending students have similar expectations as evidenced in the responses given to our market research. In considering a program of study, respondents placed considerable value on real world learning in the workplace and preparation for industry certifications as being of high importance. Additionally, intenders ranked programs with strong industry links and an emphasis with a 'hands-on' approach to learning higher than programs with ACS accreditation.

\section{The University}

Given the imperative that all programs need to be financially viable, the University insists that any proposed program needs to attract sufficient students. Equally, a program should be strongly aligned with stated University priorities and commitments. The broad aim of preparing students at Victoria University is for lifelong learning in the four scholarship categories of discovery, application, integration, and learning. To this end, the "Graduate Capabilities" policy was developed with the stated objective of improving employment outcomes for its graduates (Miliszewska \& Tan, 2004). To further improve graduate work-readiness, the University's Learning in the Workplace and Community (LiWC) policy requires that each program include a workplace learning component; the workplace is being seen more favorably as a legitimate site for contextualized learning where the gap between theory and practice can be bridged. Furthermore, the University expects that all programs provide students with multiple entry points so that, regardless of an individual's academic background, they will have many options to enroll in, study, and complete the degree.

\section{Industry \& the Professional Body}

The endorsement of a professional accreditation ensures international and local credibility for an ICT program and it enhances marketability (ACS, 2003; Jones \& Price, 2002; Ramakrishnan, 2007). The requirements of the ACS accreditation body insist that programs cover essential industry skills, such as project management, interpersonal communication, and professional practice, together with a capstone task providing students with an opportunity to work on a real-life development project (Tan, 2008). Therefore, the new course must contain sufficient depth and breadth to satisfy the accreditation requirements to the Professional level. Equally important, accreditation panels are interested in quality assurance processes the University has in place to maintain academic standards; their concern centres on outcomes and benchmarking activities associated with these assurance processes.

\section{Deciding the Program Structure}

Through scoping the needs of stakeholders the program development team began to formalize the degree structure for the Bachelor of Information Technology in Network and Systems Computing. Importantly, there would be a noticeable shift in emphasis from the traditionally theoretical offerings to a program with a more practical orientation where students will be prepared for 
sought-after industry certifications. The degree would be expected to fill a market need for graduates skilled in systems administration with networking expertise. Graduates would be employable in roles such as computing and network support, web-based programming, networking and systems administration, system security consultancy, database administration, business analysis, and project management in public and private sectors.

In defining the Bachelor of Information Technology in Network and Systems Computing program structure, three main areas of study were identified: core, support, and professional development fields, to fulfil accreditation requirements and suitably prepare graduates for roles listed above. With a strong emphasis on all major aspects of networking, the core area of Networks and Communications would necessitate at least $33 \%$ of the program content. In support of this major study in networking, units devoted to computer systems, programming, and database systems were identified as necessary to prepare students for the rigor of the core material. These support units together with the professional development units help develop skills necessary for professional practice as specified by the accreditation body. The three main areas of study are shown in Table 1 with their composite units.

Table 1: The areas of study and their component units proposed for the Bachelor of Information Technology in Network and Systems Computing at Victoria University.

\begin{tabular}{|l|l|l|l|l|}
\hline \multicolumn{2}{|c|}{ CORE } & \multicolumn{2}{|c|}{ SUPPORT } & \multicolumn{1}{|c|}{$\begin{array}{l}\text { PROFESSIONAL } \\
\text { DEVELOPMENT }\end{array}$} \\
\hline Networks and Communications & $\begin{array}{l}\text { Computer Systems, Programming } \\
\text { and Database Systems }\end{array}$ & $\begin{array}{l}\text { Professional } \\
\text { Development }\end{array}$ \\
\hline $\begin{array}{l}\text { Computer Net- } \\
\text { work Concepts }\end{array}$ & $\begin{array}{l}\text { Wireless } \\
\text { Networks }\end{array}$ & $\begin{array}{l}\text { Introduction to } \\
\text { Computer Sys- } \\
\text { tems }\end{array}$ & $\begin{array}{l}\text { Programming } \\
\text { Principles }\end{array}$ & $\begin{array}{l}\text { Communication \& } \\
\text { Information Management } \\
\text { Or an Approved Elective }\end{array}$ \\
\hline $\begin{array}{l}\text { Network Com- } \\
\text { munications \& } \\
\text { Routing }\end{array}$ & $\begin{array}{l}\text { Active Directory } \\
\text { Design \& } \\
\text { Management }\end{array}$ & $\begin{array}{l}\text { Security, Privacy } \\
\text { and Ethics }\end{array}$ & $\begin{array}{l}\text { Programming for } \\
\text { Networks }\end{array}$ & $\begin{array}{l}\text { Introduction to the } \\
\text { Computing Profession }\end{array}$ \\
\hline $\begin{array}{l}\text { Network } \\
\text { Security }\end{array}$ & $\begin{array}{l}\text { Network } \\
\text { Management }\end{array}$ & $\begin{array}{l}\text { Operating } \\
\text { Systems }\end{array}$ & $\begin{array}{l}\text { Web Design \& } \\
\text { Programming }\end{array}$ & $\begin{array}{l}\text { IT Project Management } \\
\text { (PMBOK) }\end{array}$ \\
\hline $\begin{array}{l}\text { Server } \\
\text { Administration } \\
\& \\
\text { Maintenance }\end{array}$ & $\begin{array}{l}\text { Advanced } \\
\text { Network }\end{array}$ & $\begin{array}{l}\text { Virtualisation in } \\
\text { Computing }\end{array}$ & $\begin{array}{l}\text { Introduction to } \\
\text { Systems } \\
\text { Analysis \& } \\
\text { Databases }\end{array}$ & $\begin{array}{l}\text { Computing Project Analysis } \\
\text { \& Design }\end{array}$ \\
\hline & & $\begin{array}{l}\text { Web-based } \\
\text { Systems } \\
\text { Development }\end{array}$ & $\begin{array}{l}\text { Small IT Business } \\
\text { Development }\end{array}$ \\
\hline & & $\begin{array}{l}\text { Multi-user } \\
\text { Database } \\
\text { Systems }\end{array}$ & $\begin{array}{l}\text { Computing Project } \\
\text { Development \& } \\
\text { Implementation }\end{array}$ \\
\hline
\end{tabular}

In fleshing out the proposed areas of study and their component units, staff investigated the possibility of incorporating industry-based certifications within the program. In tandem with the noted student interest in workplace learning and preparation for industry certifications, academic 
staff committed to facilitating some certifications within units of study, where theory could be tied to industry practice. This approach would allow students to gain relevant practical, hands-on work-related experience thus ensuring currency and relevance of the proposed program. In following this philosophy, the program development team extensively surveyed industry certification courses in area of networks and systems computing to match a set of identified skills needed by graduates. These skills include understanding and manipulation of computer network and communication requirements, network operating systems, routing and switching fundamentals, security, wireless, broadband and web technologies, virtual machines, and other advanced network technologies.

Two major vendors were identified, being Cisco and Microsoft, who offered relevant industry certifications allied to proposed units within the program. Both vendors are multinational corporations in computer technologies; Microsoft develops and supports a wide range of software, whereas Cisco is involved in networking and communications technologies. Specifically, several Cisco certificates were found to particularly suitable in supporting the core area of Networks and Communications studies, whilst several Microsoft certificates matched the core area as well as some of the supporting units. The mapping of industry certificates to the content of related units is shown in Table 2.

Table 2: Mapping of industry certificates to units of study of the Bachelor of Information Technology in Networks and Systems Computing at Victoria University.

\begin{tabular}{|c|c|c|}
\hline Vendor & Certificate & Units of Study \\
\hline \multirow{7}{*}{ Cisco } & \multirow[t]{4}{*}{$\begin{array}{l}\text { Cisco Certified Network Associate } \\
(\mathrm{CCNA} \AA)\end{array}$} & ECB1131 Computer Network Concepts \\
\hline & & $\begin{array}{l}\text { ECB1232 Computer Communications \& } \\
\text { Routing }\end{array}$ \\
\hline & & ECB2241 Wireless Networks \\
\hline & & $\begin{array}{l}\text { ECB3244 Advanced Networks } \\
\text { Technologies }\end{array}$ \\
\hline & $\begin{array}{l}\text { Cisco Certified Network Associate Secu- } \\
\text { rity (CCNA } ® \text { Security) }\end{array}$ & ECB2234 Network Security \\
\hline & $\begin{array}{l}\text { Cisco Certified Network Professional } \\
\left(\mathrm{CCNP}{ }^{\circ}\right)\end{array}$ & ECB3143 Network Management \\
\hline & $\begin{array}{l}\text { Cisco Certified Design Associate } \\
(\mathrm{CCDA} \circledast)\end{array}$ & $\begin{array}{l}\text { ECB3244 Advanced Networks } \\
\text { Technologies }\end{array}$ \\
\hline \multirow[t]{4}{*}{ Microsoft } & $\begin{array}{l}\text { Microsoft Certified Technology Special- } \\
\text { ist (MCTS): .NET Framework } 2.0 \mathrm{Web} \\
\text { Applications }\end{array}$ & $\begin{array}{l}\text { ECB } 2124 \text { Web-based Systems } \\
\text { Development }\end{array}$ \\
\hline & $\begin{array}{l}\text { MCTS: Windows Server } 2008 \text { Network } \\
\text { Infrastructure Configuration }\end{array}$ & $\begin{array}{l}\text { ECB3135 Server Administration \& } \\
\text { Maintenance }\end{array}$ \\
\hline & $\begin{array}{l}\text { MCTS: Windows Server } 2008 \text { Active } \\
\text { Directory Configuration }\end{array}$ & $\begin{array}{l}\text { ECB } 3142 \text { Active Directory } \\
\text { Administration }\end{array}$ \\
\hline & $\begin{array}{l}\text { MCTS: Windows Server Virtualization, } \\
\text { Configuration }\end{array}$ & ECB 3215: Virtualization in Computing \\
\hline
\end{tabular}

An analysis of Table 1 and Table 2 shows that in total there are 10 units of study which lend themselves to facilitating industry certification. Of these 10, 8 units are core units and 2 supporting units. Interestingly, 6 of the 8 core units are associated with Cisco qualifications, with Micro- 
soft covering the rest. Further examination of Table 1 shows a progression of units as one descends each column from introductory, through intermediate, to advanced level content. By arranging introductory units together, a suitable first year program was proposed, and the process repeated for intermediate and advanced units into the second and third years of the degree program, respectively. The arrangement of units across 6 semesters of the 3 year undergraduate degree program is detailed in Table 3 , where each unit is displayed with its necessary prerequisite studies, in brackets.

Table 3: Structure of the degree program, Bachelor of Information Technology in Network and Systems Computing at Victoria University. Units have been shaded to indicate units tied to possible industry certifications.

\begin{tabular}{|c|c|c|c|c|}
\hline \multicolumn{5}{|c|}{ Year 1} \\
\hline Sem1 & $\begin{array}{l}\text { ECB1131 } \\
\text { Computer Network } \\
\text { Concepts } \\
\text { (Nil) }\end{array}$ & $\begin{array}{l}\text { ECB1121 Programming } \\
\text { Principles } \\
(\text { Nil) }\end{array}$ & $\begin{array}{l}\text { ECB1111 Introduction } \\
\text { to Computer Systems } \\
\text { (Nil) }\end{array}$ & $\begin{array}{l}\text { ECB } 1151 \\
\text { Communication \& In- } \\
\text { formation Management } \\
\text { Or an Approved Elec- } \\
\text { tive } \\
\text { (Nil) }\end{array}$ \\
\hline Sem2 & $\begin{array}{l}\text { ECB1232 } \\
\text { Network Communica- } \\
\text { tions \& Routing } \\
\text { (ECB1131) }\end{array}$ & $\begin{array}{l}\text { ECB1222 } \\
\text { Web Design \& Pro- } \\
\text { gramming } \\
(\mathrm{Nil})\end{array}$ & $\begin{array}{l}\text { ECB1223 Introduction } \\
\text { to Systems Analysis \& } \\
\text { Databases } \\
\text { (Nil) }\end{array}$ & $\begin{array}{l}\text { ECB } 1252 \\
\text { Introduction to the } \\
\text { Computing Profession } \\
\text { (Nil) }\end{array}$ \\
\hline \multicolumn{5}{|c|}{ Year 2} \\
\hline Sem1 & $\begin{array}{l}\text { ECB } 2123 \\
\text { Programming for Net- } \\
\text { works } \\
(\text { ECB 1121) }\end{array}$ & $\begin{array}{l}\text { ECB2112 } \\
\text { Security, Privacy and } \\
\text { Ethics } \\
\text { (Nil) }\end{array}$ & $\begin{array}{l}\text { ECB2113 } \\
\text { Operating Systems } \\
(\text { ECB1111) }\end{array}$ & $\begin{array}{l}\text { ECB2124 } \\
\text { Web-based Systems } \\
\text { Development } \\
(\text { ECB1222) }\end{array}$ \\
\hline Sem2 & $\begin{array}{l}\text { ECB } 2234 \\
\text { Network Security } \\
(\text { ECB1232) }\end{array}$ & $\begin{array}{l}\text { ECB } 2241 \\
\text { Wireless Networks } \\
(\text { ECB1131) }\end{array}$ & $\begin{array}{l}\text { ECB2225 } \\
\text { Multi-user Database } \\
\text { Systems } \\
\text { (ECB1223) }\end{array}$ & $\begin{array}{l}\text { ECB2253 } \\
\text { IT Project Management } \\
(\text { ECB1121, ECB1252) }\end{array}$ \\
\hline \multicolumn{5}{|c|}{ Year 3} \\
\hline Sem1 & $\begin{array}{l}\text { ECB } 3142 \\
\text { Active Directory } \\
\text { Design \& Management } \\
\text { (ECB 1232) }\end{array}$ & $\begin{array}{l}\text { ECB } 3143 \\
\text { Network Management } \\
\text { (ECB1232) }\end{array}$ & $\begin{array}{l}\text { ECB3135 } \\
\text { Server Administration \& } \\
\text { Maintenance } \\
\text { (ECB 1232) }\end{array}$ & $\begin{array}{l}\text { ECB3154 } \\
\text { Computing Project } \\
\text { Analysis \& Design } \\
\text { (ECB2123, ECB2124, } \\
\text { ECB2253) }\end{array}$ \\
\hline Sem2 & $\begin{array}{l}\text { ECB } 3244 \text { Advanced } \\
\text { Network Technologies } \\
\text { (ECB2234, ECB 2241) }\end{array}$ & $\begin{array}{l}\text { ECB3214 Virtualisation } \\
\text { in Computing } \\
\text { (Nil) }\end{array}$ & $\begin{array}{l}\text { ECB3255 } \\
\text { Small IT Business } \\
\text { Development } \\
\text { (ECB1252) }\end{array}$ & $\begin{array}{l}\text { ECB3256 Computing } \\
\text { Project Development \& } \\
\text { Implementation } \\
\text { (ECB3154) }\end{array}$ \\
\hline
\end{tabular}




\section{The Issues}

Examination of Table 3 shows that students are progressively introduced to learning in the workplace material and certification opportunities over the three years of their program. Although students will be nurtured by the incremental development in the core and support areas of study, their participation in certification examinations would be encouraged but be entirely voluntary. For their professional development skills, students encounter professional development units early in the program where they are encouraged to improve their communication skills through a study of the computing profession. These communication and organizational skills are strengthened by studies in IT project management and through undertaking year-long projects where students solve real world problems for an industry or community client. Through these projects, students develop practical network and systems computing solutions for their host organizations. The inclusion of this capstone task benefits the students through exposure to technical and business mentoring, current industry practices, and an opportunity to clarify career goals (Calway, 2006; Trigwell \& Reid, 1998) as well as preserving one of the historical strengths of the traditional computing programs.

From the University's perspective, the proposed Bachelor of Information Technology in Networks and System Computing holds considerable promise in attracting new cohorts of students as evidenced in the extensive market research data collection. In implementing the new program, a major commitment to resources and staffing will need to be met. To this end, whether there will be an investment in professional development for existing staff to up-skill or a program of staff renewal will take place is yet to be decided. A major investment in network infrastructure and computing facilities for practical work is called for, particularly as 10 units of study have related certification needs. In response, a novel approach has been proposed and accepted in principle. The approach is a joint partnership of the degree program with the University Information Technology Services Department, whereby technicians in the department will liaise with academics to facilitate the necessary hands-on industry related experiences for students.

The new degree program will pose a number of challenges for academic staff. There will be a number of opportunities for staff development and industry liaisons. There will be new demands such as investigating authentic ways of assessing students in a more practically orientated program. Another consideration in designing the new proposal will be in meeting the academic rigor as required for ACS accreditation for the program.

The proposed program has been designed to take into account a major consideration for prospective students intending to work in the ICT industry, i.e. work-place learning and preparation for industry certifications. With much practical emphasis in the program, it is expected to have appeal to those interested in studying networks and system computing and have a wide catchment within the student population. Prospective students will be secondary school graduates, matureage return-to-study learners, and articulating students furnished from pathways with various feeder colleges. With adequate marketing supported by staff and funded by the University, it is hoped that the proposed new structure will appeal to those seeking sought-after industry certifications.

\section{References}

ACS - The Australian Computer Society. (2003). Accreditation of courses at the professional level Guidelines for applicants. ISBN $090992564 \mathrm{X}$.

ACS - The Australian Computer Society. (2009). IT sheds its geeky image - A tech career now the top career choice for Aussie teens. Retrieved October 2009 from http://www.acs.org.au/news/240709.htm

Booth, D. (2009). Further investigation of ICT programs at Victoria University 2009. An internal report, Victoria University, Melbourne, Australia. 
Calway, B. A. (2006). What has work-integrated learning learned? - A WIL philosophy, industry and higher education. IP Publishing UK. Retrieved April 2008 from http://centreforefs.com/resources/b calway 2006.pdf

Clemson University. (2007). School of Computing. Retrieved September 2007 from http://www.cs.clemson.edu/

Dang, A. (2009). ICT contractor work opportunities on the up, Peoplebank blog and updates website. Retrieved in November, 2009 from http://www.peoplebank.com.au/blog/2009/07/23/ict-contractor-workopportunities-on-the-up/

Dychtwald, K., Erickson, T. J., \& Morison, R. (2006). Workforce crisis: How to beat the coming shortage of skills and talent. Harvard Business School Press. ISBN I-59139-521-6.

Finkelstein, L., \& Hafner, C. (2002). The evolving discipline(s) of IT (and their relation to computer science): A framework for discussion. Retrieved October 2007 from http://www.cra.org/Activities/itdeans/finkelstein.pdf

Garnett, P. J. (2009). Investigation of VU's School of Engineering and Science course and staff profile. An internal report, Victoria University, Melbourne, Australia.

Gruba, P., Moffat, A., Sondergaard, H., \& Zobel, J. (2004). What drives curriculum change? Proceedings of Sixth Australasian Computing Education Conference (ACE2004), Dunedin, New Zealand. Conferences in Research and Practice in Information Technology, Vol. 30, 109-117.

Henkel, M., \& Kogan, M. (1999). Changes in curriculum and institutional structures. In C. Gellert (Ed.), Innovation and adaptation in higher education (Chapter 2). London: Jessica Kingsley Publ.

Hurst, J., Carbone, A., Eley, M., Ellis, A., Hagan, D., Markham, S., Sheard, J., \& Tuovinen, J. (2001). Teaching ICT: The report on learning outcomes and curriculum development in major university disciplines in Information and Communication Technology. Higher Education Division, Department of Education, Training and Youth Affairs.

Jones, L., \& Price, A. (2002). Changes in computer science accreditation. Communications of the ACM, 45(8), 99-103.

Liu, J. (2007, May). Computing as an evolving discipline: 10 Observations. Computer - IEEE Computer Society magazine. Retrieved in June, 2007 from http://www.computer.org/portal/site/computer/menuitem.5d61c1d591162e4b0eflbd108bcd45f3/index. isp? \&pName $=$ computer level1_article\&TheCat=1015\&path $=$ computer/homepage/May07\&file=profes $\underline{\text { sion.xml\&xsl=article.xsl\& }}$

Melymuka, K. (2006). Workforce crisis: Preparing for the coming IT crunch. ComputerWorld. Retrieved in August, 2007 from http://www.computerworld.com/action/article.do? command=viewArticleBasic\&articleId=112240

Miliszewska, I., \& Tan, G. (2004). Realising core graduate attributes in computer science through a CPR (Collaboration-Participation-Relevance) approach to teaching. In F. Sheehy \& B. Stäuble (Eds.), Proceedings of Research and Development in Higher Education Conference, Miri, Malaysia, CD-ROM.

Monash University. (2007). School of Information Technology. Retrieved October 2007 from http://www.infotech.monash.edu.au/

Multimedia Victoria (MMV). (2007). ICT skills research - Attitudes to ICT careers and study among 14-19 year old Victorians (Year 9-12). Retrieved September 2007 from http://www.mmv.vic.gov.au/uploads/downloads/Skills_careers/ICTSkillsResearchFINALPDF.pdf

Novotny, O., \& Doucek, P. (2007). Is the ICT university degree the best option for being a successful ICT professional? Proceedings of Computer Science + Information Technology Education Conference (CSITEd 2007), November 16-18, 2007, Mauritius, 537-548. Retrieved from http://csited.org/2007/50NovoCSITEd.pdf 
Ramakrishnan, S. (2007). Accreditation of Monash University Software Engineering (MUSE) program, International Journal of Issues in Informing Science and Information Technology, 4, 73-89. Retrieved from http://proceedings.informingscience.org/InSITE2007/IISITv4p073-089Rama272.pdf

Sharda, N. (2007). Creating innovative new media programs: need, challenges, and development framework. Proceedings of the international workshop on Educational multimedia and multimedia education, Augsburg, Bavaria, Germany, 77-86.

Skilbeck, M., \& Connell, H. (1999). Quality assurance and accreditation in Australia higher education. Department of Education, Training and Youth Affairs (DETYA).

Tan, G. (2008). ACS accreditation: What's in the name? Proceedings of the EDU-COM 2008 Conference, November 19-21, 2008, Khon Kaen, Thailand, 464-473. Retrieved in November, 2009 from http://www.chs.ecu.edu.au/org/international/documents/EDUCOM2008-Conference-Proceedings.pdf

Trigwell, K., \& Reid, A. (1998). Introduction: Work-based learning and the students' perspective. Higher Education Research \& Development, 17(2), 141-158.

Venables, A., Tan, G., Devi Nagappan, S., \& Ghous, A. (2006). Everything we wanted to know about our course, but were afraid to ask? Views from a students' perspective. Proceedings of 2006 Information Resources Management Association International Conference (IRMA). May 21-24, 2006, Washington. D.C. USA, 2, 595-598.

Victoria University (VU). (2009). VU Bachelor of Information Technology in Network and Systems Computing - New course feasibility study. An internal university report

\section{Biographies}

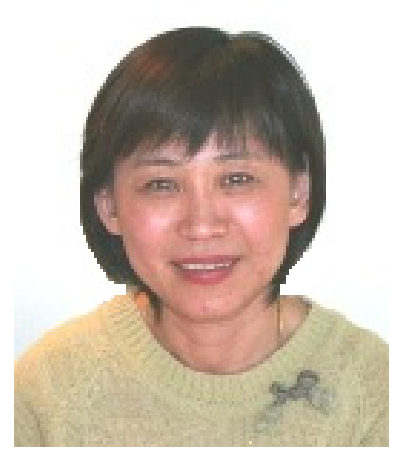

Grace Tan is a senior lecturer in Computer Science at Victoria University, Melbourne, Australia. Her research interests include investigations of innovative teaching methods, the development of graduate attributes, and issues related to female students in computing courses and Grace has published in these areas.

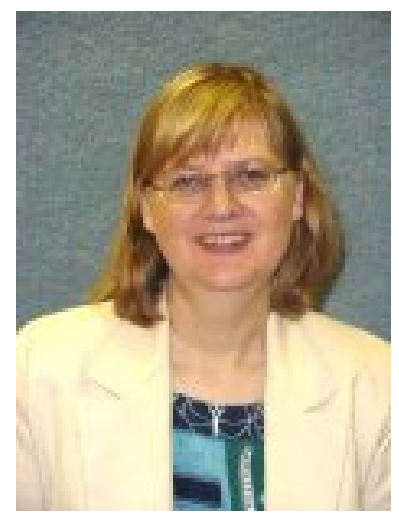

Anne Venables lectures in Computer Science and Information Technology at Victoria University, Melbourne, Australia. She has research and teaching interests in innovations in computing education and the application of intelligent systems in biological systems. 